\title{
Phenotypic Diversity of Apple (Malus sp.) Germplasm in South Serbia
}

\author{
Evica Mratinić and Milica Fotirić Akšić* \\ Faculty of Agriculture; University of Belgrade; Nemanjina 6, 11080 Belgrade-Zemun; Serbia
}

\begin{abstract}
To determine the overall degree of polymorphism, detect similarities among the accessions and collect highly valued genotypes of native apples, 21 characters of 18 autochthonous apple cultivars were studied for three years. Particular individual accessions were selected from the south region of Serbia according to economically valuable characters and tested in situ. Agronomic evaluation of germplasm accessions revealed considerable diversity among different accessions for all the characters studied. The analysis of variance revealed significant differences among the accessions and among years for some characters as well. Cluster analysis distinguished Malus sp. accessions into three distinct groups. Despite of the significant differences among the accessions, yield and fruit weight were a clear separation between the clusters. Among the germplasm of a small geographic area, it was possible to find the cultivars with valuable morphological traits that could be immediately distributed to the market or employed in breeding programs.
\end{abstract}

Key words: apple, cluster analysis, diversity, genetic resources, Serbia

\section{INTRODUCTION}

The species belonging to the genus Malus are found in the wild almost continuously throughout the temperate Eurasia and North America. The primary centre of diversity appears to be within a region stretching from Asia Minor to the western provinces of China (Juniper et al. 1999). Archaeological evidence for the spread of apple from the central Asia is scanty, but the apple has doubtlessly spread by the travellers on the great trade routes, running from the central Asia to the Danube (Clement 2005). The genus Malus is characterized by a large diversity resulted from the accumulation of somatic mutations and fostered by the human activities during the long history of the cultivation (Muzher et al. 2007). The domestication of the apple started when wild genotypes are introduced into cultivation, consciously by applying the selection in order to obtain certain traits, and unconsciously by automatic selection of the wild genotypes from their original wild environments (Ulukan 2009). Knowledge regarding the path of domestication is unclear and so far, various scenarios have been proposed for the origin of the today's apple (Evans 1993).

Normally, apple production focuses on regular plantations established with a few highly productive cultivars of extraordinary quality. However, great quantities of apples are produced in small orchards, established with local, stress resistant cultivars, having good pomological qualities that are superior to cultivated cultivars and form a huge reservoir of variability. These cultivars have been selected locally, but they also satisfy the acceptance of local consumers, having

\footnotetext{
*Author for correspondence: fotiric@agrif.bg.ac.rs
} 
more flavours likely due to its less spraying (Pereira-Lorenzo et al. 2009).

Apple germplasm and the maintenance of genetic diversity are important to future breeding because genetic diversity gives species the ability to adapt to changing environments (Bull and Wichmann 2001) and provide the raw material to breed new cultivars via hybridization (Doebley et al. 2006) or selection (Dzhangaliev 2003). Some of the resistant local cultivars could be used in the breeding programs in order to transfer the polygenic resistance although many of them have undergone genetic erosion. It is estimated that, approximately, only $20-22 \%$ of the apple genetic resources survived gene pool decreasing (Avanzato and Raparelli 2005).

Presently, the public awareness about the worldwide loss of genetic diversity in the cultivated plant species has considerably increased in recent years. The knowledge in local apple cultivars is rising up, so this kind of a situation can serve to diversify the apple market (Itoiz and Royo 2003; Pereira-Lorenzo et al. 2007). There are numerous apple genetic resources conservation and utilization programs in different countries such as in Russia (Forsline 1993), Kazakhstan (Hokanson et al. 1998), New Zealand (Noiton 1998), China (Zhi-Qin 1999), Turkey (Ercisli 2004), Romania (Gradinariu et al. 2003), Spain (Pereira Lorenzo et al. 2003) and Denmark (Larsen et al. 2006) that are trying to establish the collections of germplasm in situ. However, these efforts have not been enough to compare the complete variability found in the world.

The standardization and globalization in apples marketing in Serbia have hardly reduced the number of cultivated autochthonous cultivars and the genetic base of the cultivated apples has greatly eroded over the time as regional cultivars have been replaced (Nenadović-Mratinić and Vulić 1988).

While important genetic diversity has been observed in the autochthonous apple cultivars regarding some quality parameters studied, research and utilization of apple genetic resources has a long tradition in Serbia. Various researchers and breeding stations have been gathering cultivars since the beginning of the last century, especially during the last 50 years, such as Jovančević (1959), Stanković and Mišić (1978), Vujanić-Varga et al. (1994), Miletić et al. (1997; 2003), Mratinić (2005).
While the assessment of the level of diversity is necessary to help make the decision on management procedures (Oraguzie et al. 2001), the objective of the study was to investigate a diversity of apple autochthonous cultivars (Malus sp.) in situ from the South Serbia region not only for collecting and preserving a gene pool but for its use in apple breeding programs for creating new, better, resistant cultivars to most important diseases. Some of the selected accessions could be introduced for table consumption or for fruit processing industries.

\section{MATERIAL AND METHOD}

Eighteen autochthonous apple (Malus sp.) accessions form the south Serbia (municipalities Vranje, Bujanovac and Preševo) were analyzed in this study. Particular individual accessions, represented as solitary trees in numerous villages of the region, were selected according to economically valuable characters and tested in situ. Trees were not trained, having free canopy form, under non-irrigated, extensive cultural practice. All the accessions were examined for a set of 21 characters used as descriptors. Fruit characteristics were measured on the fruits harvested at full maturity stage. The samples of 50 fruits per tree were harvested randomly. All the qualitative properties were characterized and evaluated using the International Board for Plant Genetic Resources (I.B.P.G.R.) descriptor (Watkins and Smith 1982). To minimize the environmental effects, data from three years (2000-2002) were collected.

Following characters were studied:

1. Duration of flowering time (DFT) was the number of days between the beginning of flowering (10\% flower opened) and end of flowering time (90\% petals dropped).

2. Blooming time (BT) was represented as the number of days from April $20^{\text {th }}$

3. Period from the blooming time till the harvest time (FBHT) was represented as the number of days from full bloom till the full maturity.

4. Fruit weight (FW) was measured by scale in $\mathrm{g}$. 5. Yield (Y) was presented as $\mathrm{kg} /$ tree.

6. Soluble solids content (SS) was determined by the refractometer (Atago, pocket PAL-1) in ${ }^{\circ}$ Brix.

7. Total sugar content (TS) was determined by Luff-Schoorl method and presented in $\%$. 
8. Titratable acidity (TA) was measured by neutralization to $\mathrm{pH} 7.0$ with $0.1 \mathrm{~N} \mathrm{NaOH}$; data were given as \% of malic acid.

9. The mineral content was obtain by drying the samples at $550^{\circ} \mathrm{C}$ in a muffle furnace.

10. Tree vigour (TV): (1) Extremely weak, (3)

Weak, (5) Intermediate, (7) Vigorous, (9) Extremely vigorous.

11. Tree habit (TH): 1) Extremely upright, (2) Extremely upright/ upright, (3) Upright, (5) Spreading, (6) Spreading/drooping, (7) Drooping, (9) Weeping

12. Susceptibility to Venturia inaequalis (scab) (SVEN): (3) Low susceptibility, (5) Medium susceptibility, (7) High susceptibility

13. Susceptibility to Podospheca leucotricha (mildew) (SPOD): (3) Low susceptibility, (5) Medium susceptibility, (7) High susceptibility. 14. Susceptibility to pests (Eriosoma lanigerum woolly aphid, Cydia pomonella - codling moth) (SPEST): (3) Low susceptibility, (5) Medium susceptibility, (7) High susceptibility.

15. Fruit shape (FS): (1.0) Globose, (1.1) Globoseconical, (1.2) Short-globose-conical, (2.0) Flat, (2.1) Flat-globose (oblate), (3.0) Conical, (3.2) Intermediate - conical, (4.0) Ellipsoid, (4.1) Ellipsoid-conical (ovate), (5.0) Oblong, (5.1) Oblong-conical.

16. Background colour (BC): (1) Red, (2) Orange, (3) Cream-white, (4) Yellow, (5) Green-yellow, (6)_Green.

17. Over colour (OC): (1) Orange, (2) Pink, (3) Red, (4) Dark red, (5) Purple, (6) Brown.

18. Russet amount (RA): (1) $0 \%$, (2) $12 \%$, (3) $25 \%$, , (4) $37 \%$, , (5) $50 \%$, (6) $62 \%$, (7) $75 \%$, (8) $87 \%$, (9) $100 \%$.

19. Fruit Attractiveness (FA): (1) Extremely poor, (3) Poor, (5) Intermediate, (7) Good, (9) Extremely good.

20. Texture (TX): (1) Extremely coarse, (3) Coarse, (5) Intermediate, (7) Fine, (9) Extremely fine.

21. Eating quality (EQ): (1) Extremely poor, (2) Very poor, (3) Poor, (4) Poor/intermediate, (5) Intermediate, (6) Intermediate/good, (7) Good, (8) Very good, (9) Extremely good.

As indicators of characters variability, means value and coefficient of variation were determined.
An Analysis of variance (ANOVA) was done, and all ANOVAs were performed using the treatments as a statistical parameter at a significance level of $\mathrm{P} \leq 0.05$. The least significant difference (LSD) when necessary was used to determine if the difference between the two accessions was large enough to be considered real at a fixed level of confidence (LSD $0.05=95 \%$ confidence and LSD $0.01=99 \%$ confidence). All the characters were used to perform the clustering of accessions into similarity groups using the method of an unweighed pair group method with arithmetic mean (UPGMA). Data processing was performed using the program 'Statistica' (StatSoft, Inc., Tulsa, Oklahoma, USA). No matter the characterization was carried on during three cultivation seasons, only one cluster was developed.

\section{RESULTS AND DISCUSSION}

The scores for the 21 variables in 18 autochthonous apple accessions are shown in Tables 1 and 2. Genotypes with different trait composition were presented as the accessions studied. The duration of flowering time (DFT) of the accessions showed a narrow range (7 days), while the blooming time (BT) of examined genotypes showed a much wider (16 days). The ripening period of the selected accessions started from the last week of September till the first week of November, and varied for 45.66 days (Table 1). For TV (Table 2), about 5.56\% showed extremely vigorous, $38.29 \%$ intermediate and $55.56 \%$ vigorous growth. Considering the disposition of the accessions over the classes of $\mathrm{TH}, 16.67 \%$ showed upright, $38.29 \%$ spreading, $33.34 \%$ spreading to drooping and only $11.11 \%$ showed drooping habit. The distribution curve revealed a predominance of the plants with intermediate to vigorous accessions having spreading canopy. This could be explained with the fact that the size of the plant was probably one of the first parameters to be considered as a goal of the selection in the local inhabitants. A high growing plant could assure a good yield potential even in low-inputs agriculture. 
Table 1 - Means value and coefficient of variation (CV) for nine pomologic characters of 18 apple accessions from south Serbia.

\begin{tabular}{|c|c|c|c|c|c|c|c|c|c|c|}
\hline Cultivar & Code & DFT $^{\text {a }}$ & BT & FBHT & FW & $\mathbf{Y}$ & SS & TS & TA & MC \\
\hline Đulabija & G-1 & 7.33 & 17.33 & 140.67 & 133.33 & 223.00 & 19.20 & 10.78 & 0.31 & 0.30 \\
\hline Pečka Šerbetka & G-2 & 9.33 & 9.33 & 169.00 & 136.67 & 276.67 & 19.24 & 9.98 & 0.16 & 0.26 \\
\hline Laljče & G-3 & 8.33 & 10.33 & 168.33 & 76.67 & 300.00 & 18.43 & 12.00 & 0.82 & 0.29 \\
\hline Vizajka & G-4 & 10.00 & 10.67 & 186.33 & 145.00 & 253.33 & 18.61 & 11.06 & 0.65 & 0.24 \\
\hline Kuljača & G-5 & 8.00 & 9.00 & 182.00 & 126.67 & 82.67 & 18.91 & 11.53 & 0.21 & 0.24 \\
\hline Paša Šerbetka & G-6 & 7.00 & 20.67 & 161.33 & 106.67 & 257.67 & 17.68 & 9.80 & 0.17 & 0.27 \\
\hline $\begin{array}{l}\text { Krupna } \\
\text { Šerbetka }\end{array}$ & G-7 & 8.00 & 8.00 & 177.33 & 167.33 & 91.00 & 17.26 & 8.65 & 0.12 & 0.28 \\
\hline Buzlija & G-8 & 10.00 & 8.33 & 186.00 & 145.67 & 240.00 & 17.06 & 10.93 & 0.43 & 0.27 \\
\hline Hidži Sinan & G-9 & 9.00 & 12.67 & 177.00 & 177.33 & 96.00 & 12.55 & 11.46 & 0.22 & 0.12 \\
\hline Stambolka & G-10 & 8.33 & 4.67 & 168.33 & 70.00 & 366.67 & 17.57 & 11.64 & 0.08 & 0.24 \\
\hline $\begin{array}{l}\text { Sitna } \\
\text { Šerbetka }\end{array}$ & G-11 & 7.33 & 9.67 & 171.33 & 111.67 & 200.67 & 16.74 & 11.01 & 0.12 & 0.18 \\
\hline Avajlija & G-12 & 8.00 & 12.00 & 169.00 & 84.00 & 268.33 & 17.23 & 12.03 & 0.16 & 0.24 \\
\hline Uloćanka & G-13 & 12.33 & 13.33 & 186.00 & 141.67 & 182.00 & 16.48 & 10.73 & 0.12 & 0.18 \\
\hline Budimka & G-14 & 10.67 & 12.33 & 167.33 & 86.67 & 132.67 & 17.99 & 12.01 & 0.16 & 0.26 \\
\hline Laknja & G-15 & 9.00 & 15.00 & 177.00 & 153.33 & 89.67 & 18.14 & 11.90 & 0.17 & 0.26 \\
\hline Demirka & G-16 & 12.00 & 13.67 & 162.67 & 142.67 & 83.00 & 18.81 & 11.50 & 0.27 & 0.28 \\
\hline Pašinka & G-17 & 10.33 & 10.00 & 173.00 & 193.33 & 81.33 & 18.27 & 12.18 & 0.17 & 0.27 \\
\hline Karapaša & G-18 & 9.00 & 9.33 & 154.00 & 123.33 & 353.33 & 17.99 & 10.59 & 0.10 & 0.30 \\
\hline Mean & & 9.11 & 11.46 & 170.93 & 129.00 & 198.78 & 17.68 & 11.10 & 0.25 & 0.25 \\
\hline $\mathrm{CV}$ & & 16.84 & 32.29 & 6.85 & 26.83 & 49.01 & 8.59 & 8.34 & 80.42 & 18.77 \\
\hline \multirow{2}{*}{ LSD } & 0.05 & 1.343 & 0.909 & 2.965 & 9.725 & 105.402 & 0.480 & 0.460 & 0.044 & 0.017 \\
\hline & 0.01 & 1.945 & 1.315 & 4.293 & 14.080 & 152.610 & 0.695 & 0.665 & 0.063 & 0.024 \\
\hline
\end{tabular}

${ }^{a}$ For explanation of character symbols, see "Materials and methods"

Table 2. Qualitative characters of 18 apple accessions from south Serbia.

\begin{tabular}{|c|c|c|c|c|c|c|c|c|c|c|c|c|c|}
\hline Cultivar & Code & $\mathbf{T V}^{\mathbf{a}}$ & TH & SVEN & SPOD & SPES & FS & BC & OC & RA & FA & $\mathbf{T X}$ & EQ \\
\hline Đulabija & G-1 & 7 & 5 & 3 & 3 & 3 & 3.2 & 5 & 2 & 3 & 7 & 3 & 7 \\
\hline Pečka Šerbetka & G-2 & 5 & 5 & 3 & 3 & 3 & 4 & 3 & 3 & 3 & 9 & 1 & 7 \\
\hline Laljče & G-3 & 9 & 5 & 7 & 3 & 3 & 1 & 5 & 5 & 1 & 7 & 1 & 5 \\
\hline Vizajka & $\mathrm{G}-4$ & 7 & 5 & 3 & 3 & 3 & 3 & 5 & 3 & 1 & 5 & 5 & 4 \\
\hline Kuljača & G-5 & 5 & 3 & 7 & 3 & 3 & 1 & 3 & 3 & 1 & 9 & 3 & 4 \\
\hline Paša Šerbetka & G-6 & 7 & 6 & 3 & 3 & 3 & 1 & 3 & 2 & 1 & 5 & 3 & 6 \\
\hline $\begin{array}{l}\text { Krupna } \\
\text { Šerbetka }\end{array}$ & G-7 & 7 & 6 & 3 & 3 & 3 & 3.2 & 3 & 3 & 2 & 7 & 3 & 6 \\
\hline Buzlija & G-8 & 7 & 3 & 3 & 3 & 3 & 3.2 & 5 & 3 & 5 & 3 & 3 & 2 \\
\hline Hidži Sinan & G-9 & 5 & 6 & 3 & 3 & 3 & 2.1 & 5 & 4 & 2 & 7 & 5 & 4 \\
\hline Stambolka & G-10 & 7 & 5 & 3 & 3 & 3 & 3.2 & 4 & 3 & 2 & 7 & 3 & 3 \\
\hline Sitna Šerbetka & G-11 & 5 & 6 & 5 & 5 & 5 & 3.2 & 5 & 3 & 1 & 5 & 3 & 3 \\
\hline Avajlija & G-12 & 5 & 7 & 7 & 7 & 7 & 3.2 & 5 & 2 & 1 & 3 & 3 & 6 \\
\hline Uloćanka & G-13 & 7 & 5 & 3 & 3 & 3 & 1 & 4 & 2 & 1 & 7 & 1 & 6 \\
\hline Budimka & G-14 & 7 & 6 & 7 & 3 & 3 & 2.1 & 3 & 2 & 4 & 5 & 3 & 3 \\
\hline Laknja & G-15 & 5 & 6 & 3 & 3 & 3 & 4.1 & 3 & 3 & 1 & 7 & 1 & 5 \\
\hline Demirka & G-16 & 7 & 5 & 3 & 3 & 3 & 1.2 & 5 & 3 & 2 & 7 & 7 & 7 \\
\hline Pašinka & G-17 & 5 & 3 & 7 & 5 & 5 & 2.1 & 3 & 2 & 2 & 3 & 3 & 6 \\
\hline Karapaša & G-18 & 7 & 7 & 3 & 3 & 7 & 1 & 4 & 2 & 1 & 9 & 3 & 5 \\
\hline
\end{tabular}

\footnotetext{
${ }^{\text {a }}$ For explanation of character symbols, see "Materials and methods"
} 
FW (Table 1) varied between 70.00 (G1-10) to $193.33 \mathrm{~g}$ (G-17). Similar findings have been reported by Pirlak et al. (2003) for some local apple cultivars with $\mathrm{FW}$ values between 49.5 and 152.2 g. If genetics, environment and cultural practices interact to determine the eventual fruit size, and since the accessions in the present study had almost the same environmental conditions with almost no cultural practice, it could be concluded that the accessions G-7, G-9 and G-17 (with the average fruit weight 167.3, 177.3 and $193.3 \mathrm{~g}$, respectively) had good genetic potential for this character.

Another character to be taken into consideration was the yield that varied from 81.33 to 366.67 $\mathrm{kg} /$ tree and showed big differences between the genotypes which was confirmed by the coefficient of variation $(\mathrm{CV}=49.01 \%)$. From 18 apple accession grown in the south part of Serbia (Table 1), $33.33 \%$ of them had yield below $100 \mathrm{~kg} /$ tree, $11.11 \%$ had $100-200 \mathrm{~kg} /$ tree, $38.89 \%$ yielded 200 $300 \mathrm{~kg} /$ tree and the $16.67 \%$ over $300 \mathrm{~kg} /$ tree. The alternate bearing in the genotypes was present in all the accessions. Low chemical and fertilizer application due to a poor status of the agriculture could protect the environment; therefore, the performances of these accessions, especially in terms of yield efficiency, must be further evaluated.

Soluble solid content (SS) varied from 12.55 to $19.24 \%$. TS were between 8.65 and $12.18 \%$, while TA content was between 0.10 and $0.82 \%$ (Table 1). Similar findings have been reported for the local apple cultivars grown in Pakistan, with SS values varied from 11.80 to $14.25 \%$ and TA between 0.31 and $0.39 \%$ (Asif et al. 2004). Bostan (2009) reported SS values from 10.50 to $15.00 \%$, which was in agreement with the present results.

Considering the fact that the apple cultivars with sugar/acid ratios lower than 20 are sharp and appropriate for processing and cider production (Lea 1995), only two accessions could be used for cider production (G-3 and G-4) and the others for direct consumption.

The most dominant and harmful pathogens in apple production are scab (Venturia inaequalis) and powdery mildew (Podosphaera leucotricha), while the most common pests are woolly aphid (Eriosoma lanigerum) and codling moth (Cydia pomonella). By evaluation of data (Table 2), majority of examined accessions could be used as sources for scab, mildew and pests resistance, because it showed low susceptibility.
FS was controlled by both the climatic and nonclimatic factors, and varied greatly. It was classified in eight groups ranging from shortglobose-conical, conical, ellipsoid-conical and ellipsoid (all 5.56\%, respectively) to flat-gobose $(16.67 \%)$, globose $(27.78 \%)$ and intermediatedconical (33.33\%).

Skin colour has two components - background colour and over colour. BC varied from creamwhite $(38.89 \%)$, over yellow $(16.67 \%)$ to greenyellow $(44.44 \%)$, while OC ranged from red $(50.0 \%)$ to dark red or purple (5.56\%).

EQ depends upon the sweetness, acidity, astringency and aroma. No matter the fact that the traditional breeding practice has been to rely on the experience and opinions of one or two individuals to identify the tastiest accessions, these were classified them in six EQ categories. The majority of the accessions (27.77\%) had intermediate to good $\mathrm{EQ}$.

Looney (1993) suggested that large fruit size, attractive appearance and characteristic or distinctive flavour were amongst the most important fruit quality attributes. Considering this fact, accessions G-7, G-13 and G-16 could be placed in the quality group since had fruit weight over $140 \mathrm{~g}$, good fruit attractiveness and good eating quality. Link (2000) reported that quality components included the attributes such as size, colour, russet amount and chemical composition of the fruits, and in that case only accession G-16 could stayed in this group.

Agronomic evaluation of germplasm accessions revealed considerable diversity among different accessions for all the characters studied. The analysis of variance revealed significant differences among the accessions and among the years for some characters as well. The highest $\mathrm{F}$ value (Table 3) was obtained for TA (181.38), as a result of the particularly high acids content in the accession G-3 (0.82\%). The acknowledgment of such large dissimilarity in TA was confirmed by the coefficient of variation that had the highest value among all the characters studied $(\mathrm{CV}=80.42 \%)$. Since inter-accession differences were highly significant, the local apple cultivars studied here could be considered to be statistically different. This was quite interesting because the accessions were not selected from various areas which were distinct in the environmental and agricultural parameters. On the other hand, these could be expected so, because the intention was to collect the largest diversity possible. 
Table 3 - F-values obtained in the ANOVA for the studied quantitative factors.

\begin{tabular}{|c|c|c|c|c|}
\hline Effect & df & MS & F-value & p-value \\
\hline \multicolumn{5}{|c|}{ Duration of flowering time } \\
\hline Cultivar & 17 & $7.06 * *$ & 7.53 & 0.00 \\
\hline Year & 2 & 1.72 & 1.84 & 0.17 \\
\hline Error & 34 & 0.94 & & \\
\hline \multicolumn{5}{|c|}{ Blooming time } \\
\hline Cultivar & 17 & $41.10 * *$ & 95.53 & 0.00 \\
\hline Year & 2 & $2.02 *$ & 4.69 & 0.02 \\
\hline Error & 34 & 0.43 & & \\
\hline \multicolumn{5}{|c|}{ Period from blooming time till the harvest time } \\
\hline Cultivar & 17 & $411.16^{* *}$ & 89.70 & 0.00 \\
\hline Year & 2 & 2.07 & 0.45 & 0.64 \\
\hline Error & 34 & 4.58 & & \\
\hline \multicolumn{5}{|c|}{ Fruit weight } \\
\hline Cultivar & 17 & $3594.47 * *$ & 72.96 & 0.00 \\
\hline Year & 2 & $235.50 *$ & 4.78 & 0.01 \\
\hline Error & 34 & 49.26 & & \\
\hline \multicolumn{5}{|c|}{ Yield } \\
\hline Cultivar & 17 & $28477.88 * *$ & 4.92 & 0.00 \\
\hline Year & 2 & $222734.39 * *$ & 38.49 & 0.00 \\
\hline Error & 34 & 5786.60 & & \\
\hline \multicolumn{5}{|c|}{ Soluble solid content } \\
\hline Cultivar & 17 & $6.92 * *$ & 59.00 & 0.00 \\
\hline Year & 2 & 0.02 & 0.15 & 0.86 \\
\hline Error & 34 & 0.12 & & \\
\hline \multicolumn{5}{|c|}{ Total sugar content } \\
\hline Cultivar & 17 & $2.57 * *$ & 24.37 & 0.00 \\
\hline Year & 2 & 0.06 & 0.52 & 0.60 \\
\hline Error & 34 & 0.11 & & \\
\hline \multicolumn{5}{|c|}{ Titratable acidity } \\
\hline Cultivar & 17 & $0.118 * *$ & 181.38 & 0.00 \\
\hline Year & 2 & 0.000 & 0.49 & 0.62 \\
\hline Error & 34 & 0.001 & & \\
\hline \multicolumn{5}{|c|}{ Mineral content } \\
\hline Cultivar & 17 & $0.007 * *$ & 45.493 & 0.000 \\
\hline Year & 2 & 0.000 & 1.178 & 0.320 \\
\hline Error & 34 & 0.000 & & \\
\hline
\end{tabular}

Cluster analysis. The tree-plot obtained by the cluster procedure (UPGMA) showed the accessions grouped in the clusters with their respective distances. The determination of the 'true' number of the groups in a cluster analysis is difficult but a normalized maximum distance of 120 was used here as ultimate limit for clustering that was judged to best distinguish the accessions. Cluster analysis classified 18 Malus accessions into three distinct groups (Fig. 1). By this way, two of the three clusters included a large number of accessions, while the third one included only two. Despite of the significance differences among the accessions, the yield and fruit weight were a clear separation between the clusters.

The average accession distance (AD) among the apple cultivars based on phenologic, quantitative and qualitative traits was $\mathrm{AD}=128$, ranging from $\mathrm{AD}=14$ (the most relate accessions, G-7 and G-9) to 311 (the most distantly related, G-10 and G-17). Cluster I. This group included nine accessions (G1, G-2, G-3, G-4, G-6, G-8, G-11, G-12 and G-13) which were mainly characterized by high yields that varied from $182.0 \mathrm{~kg} /$ tree (G-13) up to 300.0 
$\mathrm{kg} /$ tree (G-3) and medium fruit size. Attending to its morphological characteristics, this group displayed intermediate pomological characters between the clusters II and III. Apples from this cluster had larger fruits and lower yields than the accessions from cluster II, but smaller fruits and higher yields than in cluster III. This cluster was split off into two distinct sub-groups, defined as cluster IA and IB. Sub-group (IA) consisted of three accessions (G-1, G-11 and G-13) with lower yields than the accessions G-2, G-3, G-4, G-6, G-8 and G-12 that formed sub-group (IB).

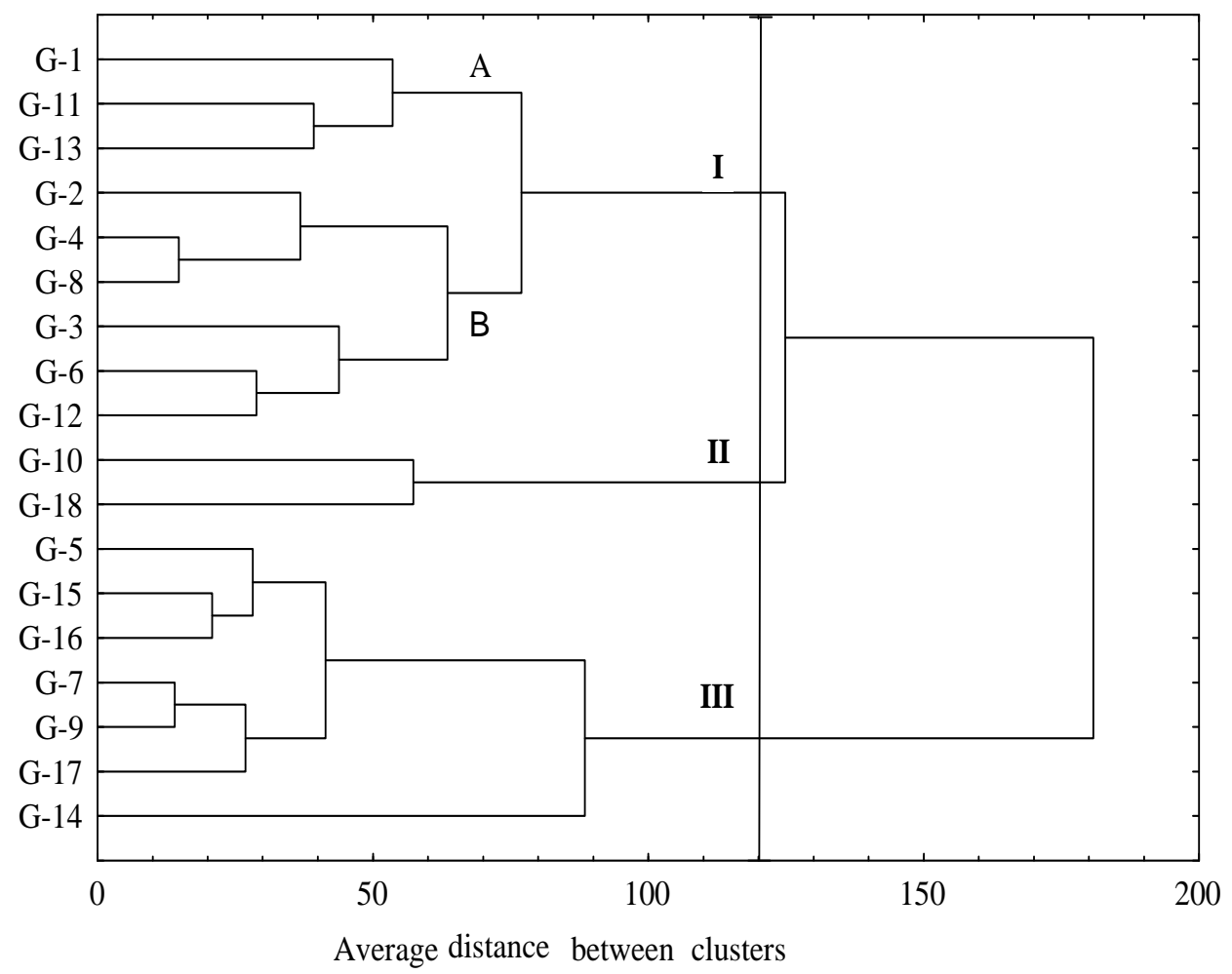

Figure 1 - Cluster resulting from the hierarchical classification of 18 autochthonous apple cultivars (Euclidean distances on the averages of the characters).

Cluster II. The second group was created by two apple accessions (G-10 and G-18). Those two had the highest yield (353.33- $366.67 \mathrm{~kg} / \mathrm{tree})$ and the lowest fruit weight $(70.00-123.33 \mathrm{~g})$ of all the cultivars examined. Actually, they shared important traits such as low mineral content, yellow ground colour, red to pink over colour and almost no russet.

Cluster III. The third cluster was created by seven accessions (G-5, G-7, G-9, G-14, G-15, G-16 and G-17). All of them had very low yields but very high fruit weight. Accessions G-5 and G-14 acted as a barrier of the cluster. This was particularly referred to G-14 because while reviewing the fruit weight and yield, it looked like that this accession was by a mistake classified in this cluster.
Hierarchical cluster analysis allowed the assessment of similarity or dissimilarity and clarified some of the relationships between the cultivars. The accessions clustered in the first two groups revealed relatively closer genetic relationships than those in cluster III. The reason of a low dissimilarity could be explained with the fact that the population of apple cultivars included the genotypes from relatively small area of dissemination and those one gone through the selection. Also, the fragmentation and reduction in the habitat size as well as isolation of population could increase the inbreeding depression which could lead to little differentiation between the local populations (McKay and Latta 2002). But, on the other hand, high dissimilarity between some accessions could be explained by the apple 
polymorphism (Pereira-Lorenzo et al. 2003, 2007) or by continuous accession introduction from other part of Balkan Peninsula or even whole Europe.

Hybridization can be a kea for both low and high dissimilarity level. If hybridization between the cultivars and their wild progenitor occurred, where both types of materials had remained in close contact for a long time (Allendorf et al. 2001), the individuals with intermediate phenotypes occurred (Coart et al. 2003). Also, it could be speculated that outcrossing and a self-incompatibility system in apple would result in higher levels of heterozygosity and continuous diversity of the accessions. But, it was, however, more apparent that the hybridization had led to the reduction of the population fitness (Lynch 1991) as well as the extinction of some cultivars (Rhymer and Simberloff 1996).

Recent observations had determined that some accessions growing in different villages had similar morphology and slightly different names. That was why a strong similarity was expected between the four accessions (G-2, G-6, G-7 and G11) that were collected in the same part of the region, and with the similar local name (having word 'Šerbetka' in its local name which means 'too sweet'), but they were placed in two different clusters. The accessions from cluster I (G-2, G-6 and G-11) were virtually identical and were grouped in the same cluster, especially G-2 and G6 that were in the same sub-cluster. Accession G-7 from cluster III was different from the previous and did not correspond to the mentioned accessions description because it had larger fruits, lower yield, and different phenology. It seemed that these accessions were probably the same cultivar in the past, but accession G-7 separated earlier and developed independently under the selection of Serbian conditions.

No matter the fact that cluster analysis separated the apple accessions from each others, it was difficult to say how many of these accessions were really originated from this area, undergone human selection or obtained from the seedlings. It was hard to assume how many of them could be a single plant imported from other part of Serbia or neighbour countries and later domesticated.

Royo and Itoiz (2004) classified apple cultivars in the clusters according to its morphological characterization and found that the fitness of the dendrogram obtained using the morphological data was poor. Forte et al. (2002) constructed dendrogram of the morphological traits for the analysis of the phylogenetic relationships among the wild and cultivated apple cultivars. Also, Damyar et al. (2007) showed that the classification of apple genotypes in the clusters, based on several quantitative and qualitative traits, had good segregation on the population.

\section{CONCLUSION}

Morphological and agronomic data analyses using the analysis of variance and cluster analysis revealed the existence of a wide variability of genus Malus in a very small area such as south Serbia. This study demonstrated that the numerical analysis of apple morphological traits could be used as a rapid and comprehensive method to establish accessions classification within the germplasm collections. Based on these results, it could be concluded that all apple cultivars of cluster I were the best sources of genotypes having high fruit weight and yield and with the longest period from the flowering till the harvest time. Genotypes G-3 and G-4 could be used for cider production. Accessions grouped into cluster II appeared to be industrial one because of the enormously high yields. Cluster III had accessions that could be used for table consumption, especially G-16 as the most quality one. Further accumulation of data across the years and across the country might result in an increase of the precision of accessions assessment. It was interesting that in each cluster, accessions could be found with low susceptibility to diseases and pest, so the cultivars could be used in future breeding program for apple improvement in all the directions. Obviously, the multiplication of representative accessions of these clusters will be given priority.

Present study confirmed the necessity of preserving these unique genetic resources and continuing its study no matter the fact that in practice. However, it was difficult to determine whether a specific genetic variant would be of future value. For this reason, all the collected accessions were transferred to the Experimental Station 'Radmilovac' of the Faculty of Agriculture in Belgrade for further study. The main goal was to ensure the conservation of a wide range of genetic variability and progress in long-term breeding program because greater genetic diversity would be desirable for future development of innovative, market-driven cultivars (Noiton 1998). 
Since the value of genetic resources can be expressed as an ecological, economical or ethical value, it should be also considered to promote the accession's come back to main markets of Serbia or surrounded countries in order to create an economical opportunity for the local farmers.

\section{ACKNOWLEDGMENTS}

The authors wish to thank the Ministry of Science and Technological Development of the Republic of Serbia for their financial support of this research, as a part of the project TR 31063 "The application of new genotypes and technology innovation for the purpose of improvement of fruit growing and viticultural productions".

\section{REFERENCES}

Allendorf FW, Leary RF, Spruell P, Wenburg JK. The problems with hybrids: setting conservation guidelines. Trends Ecol Evol. 2001; 16: 613-622.

Asif AM, Raza H, Azam KM, Hussain M. Effect of different periods of ambient storage on chemical composition of apple fruit. Int J Ag Biol. 2004; 6(2): 568-571.

Avanzato D, Raparelli E. The relationship between the agriculture modernization and the fruit genetic erosion observed by analyzing the plants offer from the nurseries catalogues. In: First International Conference on Crop Wild Relative Conservation and Use, Proceedings: Book of abstracts; 2005 Sep; Agrigento, Sicily, Italy. Birmingham: University of Birmingham 2005. p.47.

Bostan SZ. Pomological traits of local apple and pear cultivars and types grown in Trabzon province (eastern Black sea region of Turkey). Acta Hortic. 2009; 825: 293-298.

Bull JJ, Wichmann HA. Applied evolution. Annu Rev Ecol Syst, 2001; 32: 183-217.

Clement C. Fruits: In: Sir Prance G and Nesbitt M, editors. The cultural history of plants. Routledge, Madison Avenue, New York; 2005. p. 77-96.

Coart E, Vekemans X, Smudlers MJM, Wagner I, Huylenbroeck van J, Bockstaele van E, et al. Genetic variation in the endangered wild apple (Malus sylvestris (L.) Mill.) in Belgium as revealed by amplified fragment length polymorphism and microsatellite markers. Mol Ecol. 2003; 12: 845-857.

Damyar S, Hassani D, Dastjerdi R, Hajnajari H, Zeinanloo AA, Fallahi E. Evaluation of Iranian native apple cultivars and genotypes. JFAE. 2007; 5: 211215.
Doebley JF, Gaut BS, Smith BD. The molecular genetics of crop domestication. Cell 2006; 7: 1309_ 1321.

Dzhangaliev AD. The wild apple tree of Kazakhstan. In: Janick $\mathbf{J}$, editor. Wild apple and fruit trees of central Asia, Hort rev 29. John Wiley \& Sons, Inc., Hoboken, New Jersey; 2003. p. 63-285.

Evans LT. Crop evolution, adaptation and yield Cambridge University Press, Cambridge; 1993.

Ercisli SA. A short review of the fruit germplasm resources of Turkey. Genet Resou Crop Ev. 2004; 51 : 419-435.

Forsline PL. Explorers find valuable apple germplasm in remote areas of former USSR. Diversity 1993; 9(10): 31-34.

Forte AV, Ignatov AN, Ponomarenko VV, Dorokhov DB, Savelyev NI. Phylogeny of the Malus (apple tree) species, inferred from the morphological traits and molecular DNA analysis. Russ J Gene., 2002; 38(10): 1150-1160.

Gradinariu G, Istrate M, Dascalu M, Gradinariu F, Janick J. Native apple germplasm in Romania. Acta Horti., 2003; 622: 485-488.

Hokanson SC, Forsline PL, McFerson JR, Lamboy WF, Aldwinckle HS, Luby JJ, et al. Ex situ and in situ conservation strategies for wild Malus germpalsm in Kazakhstan. Acta Hortic. 1998; 484: 85-92.

Itoiz R, Royo B. Isoenzymatic variability in an apple germplasm bank. Genet Resour Crop Ev. 2003; 50: 391-400.

Jovančević R. Jabuka Dapsićanka (Krstovača). Poljoprivredni pregled 1959; 3: 3-4.

Juniper BE, Watkins R, Harris SA. The origin of the apple. Acta Hortic. 1999; 484: 27-33.

Larsen AS, Asmussen CB, Coart E, Olrik DC, Kjær ED. Hybridization and genetic variation in Danish populations of European crab apple (Malus sylvestris). Tree Genet Genomes. 2006; 2: 86-97.

Lea AGH. Cider making. In: Lea AGH and Piggott JR, eritors. Fermented Beverage Production. Blackie and Sons, Glasgow; 1995. p. 66-96.

Link H. Significance of flower and fruit thinning on fruit quality. Plant Growth Regul. 2000; 31: 17-26.

Looney NE. Improving fruit size, appearance, and other aspects of fruit crop 'quality' with plant bioregulating chemicals. Acta Hortic. 1993; 329: 120-127.

Lynch M. The genetic interpretation of inbreeding depression and outbreeding depression. Evolution 1991; 45: 622-629.

McKay JK, Latta RG. Adaptive population divergence: markers, QTL and traits. Trends Ecol Evol. 2002; 17: 285-291.

Miletić R, Žikić M, Mitić N, Nikolić R. Variability of pomological characteristics of the Šumatovka apple. Genetika 2003; 35(1): 51-58. 
Miletić R, Petrović R, Miljić S, Rajković S. Rezultati izučavanja autohtonih sorti jabuke i kruške $u$ Timočkoj krajini. Savremena poljoprivreda 1997; 56: 27-32.

Mratinić E. Autohtone sorte jabuke u Srbiji i Crnoj Gori. Prvo izdanje. Draganić, Beograd; 2005.

Muzher BM, Younis RAA, El-Halabi O, Ismail OM Genetic identification of some Syrian local apple (Malus sp.) cultivars using molecular markers. Res $J$ Agric Biol Sci. 2007: 3(6): 704-713.

Nenadović-Mratinić E, Vulić T. Autohtone sorte jabuke u potkopaoničkom regionu. Jugoslovensko voćarstvo 1988; 86: 319-324.

Noiton D, Hofstee M, Alspach P, Brewer L, Howard C. Increasing genetic diversity for apple breeding: a preliminary report. Acta Hortic. 1998; 484: 105-108.

Oraguzie NC, Gardiner SE, Basset HCM, Stefanati M, Ball RD, Bus, VGM, et al. Genetic diversity and relationship in Malus sp. germplasm collections as determined by Random Amplified Polymorphic DNA. J Am Soc Hort Sci. 2001; 126(3): 318-328.

Pereira-Lorenzo S, Ramos-Cabrer AM, AscasíbarErrasti J, Piñeiro-Andión J. Analysis of apple germplasm in Northwestern Spain. J Am Soc Hort Sci. 2003; 128(1): 67-84.

Pereira-Lorenzo S, Ramos-Cabrer AM, DiázHernández MB. Evaluation of genetic identity and variation of local apple cultivars (Malus $x$ domestica) from Spain using microsatellite markers. Genet Resour Crop Ev. 2007; 54: 405-420.

Pereira-Lorenzo S, Ramos-Cabrer AM, Fischer M. Breeding apple (Malus $\times$ domestica Borkh). In: Jain SMP and Priyadarshan PM, editors. Breeding plantation tree crops: temperate species. Springer New York, NY; 2009. p. 33-82.
Pirlak L, Güleryüz M, Aslantas RA, Eşitken A. Promising native summer apple (Malus domestica) cultivars from north-eastern Anatolia, Turkey. New Zeal J Crop Hort. 2003; 31: 311-314.

Rhymer JM, Simberloff D. Extinction by hybridization and introgression. Ann Rev Ecol Syst. 1996; 27: 83109.

Royo JB, Itoiz R. Evaluation of the discriminance capacity of RAPD, isoenzymes and morphologic markers in apple (Malus $x$ domestica Borkh.) and the congruence among classifications. Genet Resour Crop Ev. 2004; 51:153-160.

Stanković D, Mišić P. Yugoslavia - an important source of fruit gerplasm. Cron Hortic 1978; 18: 3-4.

Ulukan $\mathrm{H}$. The evolution of cultivated plant species: classical plant breeding versus genetic engineering. Plant Syst Evol. 2009; 280: 133-142.

Vujanić-Varga D, Ognjanov V, Balaž J, Macet K, Krstić M. Genetic resources in apple, pear and vineyard peach populations in former Yugoslavia. Euphytica 1994; 77(1-2): 155-159.

Watkins R, Smith RA. IBPGR Descriptor list for apple (Malus). Committee on disease resistance breeding and use of genebanks. C.E.C. Secretariat, Brussels; 1982.

Zhi-Qin Z. The apple genetic resources in China: The wild species and their distributions, informative characteristics and utilization. Genet Resour Crop Ev. 1999; 46: 599-609. 